\title{
Bacillus persepolensis sp. nov., a moderately halophilic bacterium from a hypersaline lake
}

\author{
Correspondence \\ A. Ventosa \\ ventosa@us.es
}

\author{
M. A. Amoozegar, ${ }^{1}$ C. Sánchez-Porro, ${ }^{2}$ R. Rohban, ${ }^{3}$ M. Hajighasemi ${ }^{1}$ \\ and A. Ventosa ${ }^{2}$
}

\author{
${ }^{1}$ Extremophiles Laboratory, Department of Microbiology, Faculty of Biology, College of Science, \\ University of Tehran, Tehran, Iran \\ ${ }^{2}$ Department of Microbiology and Parasitology, Faculty of Pharmacy, University of Sevilla, \\ 41012 Sevilla, Spain \\ ${ }^{3}$ Department of Biology, Islamic Azad University, Science and Research Campus, Tehran, Iran
}

Endospore-forming, moderately halophilic, Gram-positive rods are frequently isolated from saline and hypersaline environments such as soils and aquatic habitats (Arahal \& Ventosa, 2002; Ventosa, 2006). They are characterized by optimal growth in media containing 3-15\% (w/v) $\mathrm{NaCl}$ (Ventosa et al., 1998). They belong to species included in the genus Bacillus, as well as related genera. The moderately halophilic species belonging to the genus Bacillus are Bacillus aurantiacus (Borsodi et al., 2008), Bacillus chagannorensis (Carrasco et al., 2007a), Bacillus coahuilensis (Cerritos et al., 2008), Bacillus isabeliae (Albuquerque et al., 2008), Bacillus oshimensis (Yumoto et al., 2005), Bacillus polygoni (Aino et al., 2008), Bacillus qingdaonensis (Wang et al., 2007), Bacillus salarius (Lim et al., 2006c) and Bacillus taeanensis (Lim et al., 2006a). Other genera related phylogenetically to the genus Bacillus that include moderately halophilic species are Alkalibacillus (Jeon et al., 2005; Usami et al., 2007), Aquisalibacillus (Márquez et al., 2008), Filobacillus (Schlesner et al., 2001), Gracilibacillus (Wainø et al., 1999; Carrasco et al., 2006; Jeon et al., 2008), Halalkalibacillus (Echigo et al., 2007), Halobacillus (Spring

The GenBank/EMBL/DDBJ accession number for the 16S rRNA gene sequence of strain $\mathrm{HS}_{136^{\top}}$ is $\mathrm{FM} 244839$. et al., 1996; Amoozegar et al., 2003; Yoon et al., 2003, 2005, 2007a, 2008; Liu et al., 2005; An et al., 2007b; Hua et al., 2007; Romano et al., 2008; Soto-Ramírez et al., 2008), Halolactibacillus (Cao et al., 2008), Lentibacillus (Yoon et al., 2002; Namwong et al., 2005; Pakdeeto et al., 2007; Lee et al., 2008), Marinibacillus (Yoon et al., 2004a), Oceanobacillus (Lee et al., 2006), Piscibacillus (Tanasupawat et al., 2007), Pontibacillus (Lim et al., 2005), Salimicrobium (Ventosa et al., 1989; Yoon et al., 2007b), Salinibacillus (Ren \& Zhou, 2005b), Salsuginibacillus (Carrasco et al., 2007b), Sediminibacillus (Carrasco et al., 2008), Tenuibacillus (Ren \& Zhou, 2005a), Thalassobacillus (García et al., 2005) and Virgibacillus (Garabito et al., 1997; Arahal et al., 1999; Heyrman et al., 2003; Yoon et al., 2004b; Lee et al., 2006; An et al., 2007a; Chen et al., 2008; Hua et al., 2008; Wang et al., 2008). This paper describes a novel endospore-forming, moderately halophilic, Gram-positive bacterium, strain $\mathrm{HS} 136^{\mathrm{T}}$, isolated from the hypersaline lake Howz-Soltan in the centre of Iran.

Strain $\mathrm{HS}_{136^{\mathrm{T}}}$ was isolated from water of the hypersaline lake Howz-Soltan, which is located near Qom city in the centre of Iran, with an area of about 240 and $280 \mathrm{~km}^{2}$ in dry and wet seasons, respectively. The depth of the salt layer that covers almost all of the surface of the playa varies between 20 and $46 \mathrm{~m}$ and the $\mathrm{pH}$ of the water, saline soil 
and salt sediments differs between 6.5 and 8.2. The major chemical composition of the soil, brine, mud and salt consists of $\mathrm{NaCl}, \mathrm{KCl}, \mathrm{MgSO}_{4}, \mathrm{MgCl}_{2}$ and $\mathrm{Na}_{2} \mathrm{SO}_{4}$. At the time of sampling, the temperature of the water was $32{ }^{\circ} \mathrm{C}$ and the $\mathrm{pH}$ was 7.6. Strain $\mathrm{HS} 136^{\mathrm{T}}$ was isolated during studies focused on the determination of the biodiversity of the lake and constituted a single isolate of the total population. It was isolated by diluting a water sample in sterile $10 \%(\mathrm{w} / \mathrm{v})$ salt solution, plating on $10 \% \mathrm{HM}$ medium and incubating aerobically at $37{ }^{\circ} \mathrm{C}$. The $10 \%$ $\mathrm{HM}$ medium contained $\left(\mathrm{g} \mathrm{l}^{-1}\right): \mathrm{NaCl}, 81 ; \mathrm{MgCl}_{2}, 7$; $\mathrm{MgSO}_{4}, 9.6 ; \mathrm{CaCl}_{2}, 0.36 ; \mathrm{KCl}, 2 ; \mathrm{NaHCO}_{3}, 0.06 ; \mathrm{NaBr}$, 0.026; proteose peptone no. 3 (Difco), 5; yeast extract, 10; glucose, 1 (Ventosa et al., 1982). The $\mathrm{pH}$ of this medium was adjusted to 7.5. The strain was subsequently purified three times by plating on the same medium and maintained on the same $\mathrm{HM}$ medium and at $-80{ }^{\circ} \mathrm{C}$ on this medium without agar and supplemented with $30 \%$ (v/ v) glycerol. In order to characterize strain $\mathrm{HS}_{136^{\mathrm{T}}}$ phenotypically, standard phenotypic tests were performed.

Cell morphology was examined by light microscopy (model BH41; Olympus) using cells from exponentially growing cultures. Gram staining was performed by the Burke method (Murray et al., 1994) and the result was confirmed by the KOH test (Baron \& Finegold, 1990). The presence of endospores was investigated by using the Schaeffer-Fulton staining method (Murray et al., 1994). Motility was analysed by the wet-mount method (Murray et al., 1994). Catalase, oxidase and urease activities, nitrate reduction, hydrolysis of aesculin and production of indole were tested as recommended by Smibert \& Krieg (1994). Hydrolysis of Tween 80 was examined as described by Harrigan \& McCance (1976). Methyl red and VogesProskauer tests were done as recommended by Smibert \& Krieg (1994). Determination of acid production from carbohydrates, as well as utilization of carbon and nitrogen sources, was performed as recommended by Ventosa $e t$ al. (1982). Antibiotic-susceptibility tests were performed on Mueller-Hinton agar plus $10 \%(\mathrm{w} / \mathrm{v})$ sea salts (Ventosa et al., 1982) seeded with a bacterial suspension containing $1.5 \times 10^{6}$ c.f.u. $\mathrm{ml}^{-1}$ by using discs (HiMedia) impregnated with various antibiotics. The plates were incubated at $37^{\circ} \mathrm{C}$ for $48 \mathrm{~h}$ and the inhibition zone was interpreted according to the manufacturer's manual. To determine the optimal temperature and $\mathrm{pH}$ for growth of the strain, broth cultures were incubated at $10-50{ }^{\circ} \mathrm{C}$ at intervals of $5{ }^{\circ} \mathrm{C}$ and at $\mathrm{pH} 5-11$ at intervals of $0.5 \mathrm{pH}$ units. $\mathrm{pH}$ values of $<6,6-9$ and $>9$ were obtained by using sodium acetate/ acetic acid, Tris/HCl and glycine/sodium hydroxide buffers, respectively. Growth at different salt concentrations $(0,2.5,5.0,7.5,10,15,20,25$ and $30 \%, \mathrm{w} / \mathrm{v})$ was tested on $\mathrm{HM}$ medium at $\mathrm{pH}$ 8.0. Growth was monitored by turbidity at $\mathrm{OD}_{600}$ by using a spectroscopic method (model UV-160 A; Shimadzu). Other physiological and biochemical tests were performed as described previously (Ventosa et al., 1982; Quesada et al., 1984; Mata et al., 2002).
Strain $\mathrm{HS}_{136^{\mathrm{T}}}$ was Gram-positive, motile and strictly aerobic. Cells were rods with a width of $1.0-1.5 \mu \mathrm{m}$ and a length of 2.5-3.0 $\mu \mathrm{m}$. Ellipsoidal endospores were formed at the central-subterminal position in non-swollen sporangia. When grown for 2 days at $37{ }^{\circ} \mathrm{C}$ on $10 \%$ HM medium, colonies were circular, entire, smooth and cream and had a diameter of $2 \mathrm{~mm}$. This isolate was moderately halophilic and slightly alkaliphilic, growing in media containing 5-20\%(w/v) $\mathrm{NaCl}$ and optimally in medium containing $10 \%(\mathrm{w} / \mathrm{v}) \mathrm{NaCl}$. No growth was observed in the absence of $\mathrm{NaCl}$. Strain $\mathrm{HS} 136^{\mathrm{T}}$ grew between $\mathrm{pH} 7.0$ and 10.0 and optimally in media with $\mathrm{pH}$ 8.0-8.5. Other phenotypic features are included in the species description.

Genomic DNA from strain HS136 ${ }^{\mathrm{T}}$ was prepared by using the method described by Marmur (1961). The 16S rRNA gene was amplified by PCR with the forward primer 16F27 and the reverse primer 16R1488 (Márquez et al., 2008). Direct sequence determination of the PCR-amplified DNA was carried out using an automated DNA sequencer (model ABI 3130XL; Applied Biosystems). 16S rRNA gene sequence analysis was performed with the ARB software package (Ludwig et al., 2004). The 16S rRNA gene sequence was aligned with the published sequences of closely related bacteria and the alignment was confirmed and checked against both primary and secondary structures of the 16S rRNA molecule by using the alignment tool of the ARB software package. Phylogenetic trees were constructed by using three different methods: the maximumlikelihood (Felsenstein, 1981), maximum-parsimony (Fitch, 1971) and neighbour-joining (Saitou \& Nei, 1987) algorithms integrated in the ARB software for phylogenetic inference. The 16S rRNA gene sequences used for phylogenetic comparisons were obtained from GenBank and their strain designations and accession numbers are shown in Fig. 1.

The almost-complete 16S rRNA gene sequence (1474 bp) of strain $\mathrm{HS}_{136^{\mathrm{T}}}$ was obtained and used for initial BLAST searches in GenBank and phylogenetic analysis. The identification of phylogenetic neighbours and calculation of pairwise 16S rRNA gene sequence similarity were achieved by using the EzTaxon server (http://www.eztaxon. org/; Chun et al., 2007). Phylogenetic analysis based on the maximum-parsimony algorithm revealed that strain $\mathrm{HS} 136^{\mathrm{T}}$ formed a phyletic group with B. salarius $\mathrm{BH} 169^{\mathrm{T}}$ (95.2\% similarity) and B. qingdaonensis $\mathrm{CM1}^{\mathrm{T}}(94.5 \%)$ (Fig. 1). 16S rRNA sequence similarity with other Bacillus species was $\leqslant 94.5 \%$. Neighbour-joining and maximumlikelihood methods resulted in highly similar tree topologies and only the maximum-parsimony results are shown. Based on the sequence divergence, it was evident that strain HS136 ${ }^{\mathrm{T}}$ constituted a different taxon separated from other Bacillus species. DNA-DNA hybridization between strain $\mathrm{HS}_{136^{\mathrm{T}}}$ and the nearest phylogenetic neighbours was not attempted, as strains differing by $>3 \%$ of the $16 \mathrm{~S}$ rRNA gene sequence are unlikely to exhibit $>70 \%$ relatedness at 


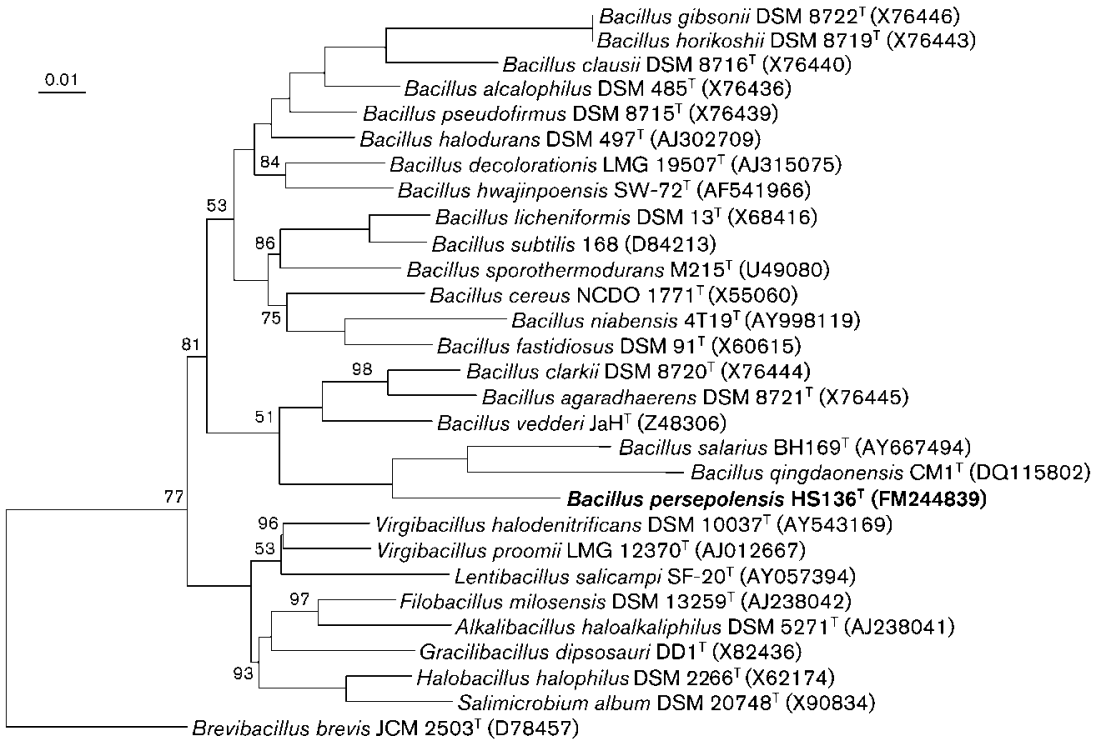

Fig. 1. Maximum-parsimony tree based on 16S rRNA gene sequence comparison, showing the relationship of strain $\mathrm{HS}_{136}{ }^{\top}$ to related species. The GenBank accession numbers of the sequences used in this study are shown in parentheses after the strain designation. Brevibacillus brevis $\mathrm{JCM} 2503^{\top}$ was used as an outgroup. Bar, 0.01 substitutions per nucleotide position. the whole-genome level (Stackebrandt \& Goebel, 1994; Stackebrandt et al., 2002; Stackebrandt \& Ebers, 2006).

The $\mathrm{G}+\mathrm{C}$ content of the genomic DNA was determined from the midpoint value of the thermal-denaturation profile (Marmur \& Doty, 1962) by using the equation of Owen \& Hill (1979). The G+C content of the DNA of strain $\mathrm{HS}_{136}{ }^{\mathrm{T}}$ was $37.1 \mathrm{~mol} \%$. This value is within the range for the genus Bacillus, but is lower than those of $B$. salarius and B. qingdaonensis (Table 1).

Fatty acid analysis was performed by using the MIDI system (Microbial ID). Cells were cultured on marine agar (Difco) containing $10 \%(\mathrm{w} / \mathrm{v}) \mathrm{NaCl}$ at $30{ }^{\circ} \mathrm{C}$ for $48 \mathrm{~h}$. Extraction and analysis were performed conforming to the recommendations of the MIDI system. This analysis was carried out by the Identification Service of the BCCM/ LMG, Gent, Belgium. The cellular fatty acid profile of strain $\mathrm{HS}_{136^{\mathrm{T}}}$ was characterized by the fatty acids iso- $\mathrm{C}_{15: 0}$ $(41.6 \%)$ and anteiso- $C_{15: 0}(35.8 \%)$ as the major fatty acids (Table 2). The fatty acid composition is similar to those found in $B$. salarius $\mathrm{BH} 169^{\mathrm{T}}$ and $B$. qingdaonensis $\mathrm{CM1}^{\mathrm{T}}$, except that the proportion of iso- $\mathrm{C}_{15: 0}$ was lower and that of anteiso- $\mathrm{C}_{17: 0}$ was higher for strain $\mathrm{HS}_{136^{\mathrm{T}}}$ than for these two Bacillus species. In order to complete the chemotaxonomic characterization of strain $\mathrm{HS}_{136^{\mathrm{T}}}$, analysis of polar lipids, quinones and peptidoglycan of the cell wall was carried out by the Identification Service of the DSMZ, Braunschweig, Germany. The polar lipids detected were phosphatidylglycerol and diphosphatidylglycerol. Strain $\mathrm{HS}_{136^{\mathrm{T}}}$ contained MK-7 as the unique menaquinone and a cell wall type based on meso-diaminopimelic acid. The respiratory lipoquinone, polar lipids and peptidoglycan type of the cell wall of strain $\mathrm{HS} 136^{\mathrm{T}}$ were typical of those found in members of the genus Bacillus (Priest et al., 1988; Heyrman et al., 2004, 2005; Wieser et al., 2005; Lim et al., 2006a, b, c).
The characteristics that differentiate strain $\mathrm{HS} 136^{\mathrm{T}}$ from related Bacillus species are summarized in Table 1. The differences in some features, such as endospore position and shape, motility, optimum temperature, acid production from carbohydrates, genomic DNA G+C content and fatty acid composition, can be used to distinguish this strain from phylogenetically related taxa (Tables 1 and 2). Therefore, on the basis of these polyphasic taxonomic data, we propose that the new strain represents a novel species of the genus Bacillus, for which the name Bacillus persepolensis sp. nov. is proposed, with the type strain $\mathrm{HS} 136^{\mathrm{T}}$.

\section{Description of Bacillus persepolensis sp. nov.}

Bacillus persepolensis (per.se.po.len'sis. N.L. masc. adj. persepolensis related to the ancient city of Persepolis, in modern-day Iran).

Cells are Gram-positive, motile, endospore-forming rods, $1.0-1.5 \times 2.5-3.0 \mu \mathrm{m}$ in size. Ellipsoidal endospores are produced at a central-subterminal position in nonswollen sporangia. Colonies are circular, entire, smooth, cream and $2 \mathrm{~mm}$ in diameter on $10 \%$ HM medium after $48 \mathrm{~h}$ incubation at $37^{\circ} \mathrm{C}$. Strictly aerobic. Slightly alkaliphilic. Moderately halophilic, growing over a wide range of $\mathrm{NaCl}$ concentrations [from 5 to $20 \%(\mathrm{w} / \mathrm{v})$ $\mathrm{NaCl}$, with optimal growth at $10 \%(\mathrm{w} / \mathrm{v}) \mathrm{NaCl}$. No growth occurs in the absence of $\mathrm{NaCl}$. Grows at $25-45{ }^{\circ} \mathrm{C}$ (optimally at $40{ }^{\circ} \mathrm{C}$ ) and $\mathrm{pH} 7.0-10.0$ (optimally at pH 8.0-8.5). Catalase- and oxidase-positive. Casein and Tween 80 are hydrolysed, but starch, gelatin, DNA and aesculin are not. Nitrate is not reduced to nitrite. Indole and $\mathrm{H}_{2} \mathrm{~S}$ are not produced. Acid is produced from Dglucose, trehalose and $m$-inositol, but not from $\mathrm{D}$ fructose, galactose, lactose, maltose, melibiose, D-mannose or D-xylose. Methyl red, Voges-Proskauer, urease, 
Table 1. Characteristics that distinguish strain $\mathrm{HS} 136^{\top}$ from related species of the genus Bacillus

Strains: $1, \mathrm{HS}_{136}{ }^{\mathrm{T}}$; 2, B. salarius $\mathrm{BH} 169^{\mathrm{T}}$ (Lim et al., 2006c); 3, B. qingdaonensis $\mathrm{CM}^{\mathrm{T}}$ (Wang et al., 2007). +, Positive; - negative; ND, not determined.

\begin{tabular}{|c|c|c|c|}
\hline Characteristic & 1 & 2 & 3 \\
\hline Cell size & $1.0-1.5 \times 2.5-3.0$ & $0.5-0.7 \times 1.3-1.9$ & $0.3-0.4 \times 1.8-3.2$ \\
\hline Pigmentation & Cream & Cream-white to yellow & Cream \\
\hline Endospore position/shape & Central-subterminal/ellipsoidal & Spherical/terminal & - \\
\hline Oxidase & + & + & - \\
\hline Motility & + & - & - \\
\hline Range & $5-20$ & $3-20$ & $2.5-20$ \\
\hline Optimum & 10 & $10-12$ & 12 \\
\hline \multicolumn{4}{|l|}{ Temperature for growth $\left({ }^{\circ} \mathrm{C}\right)$ : } \\
\hline Range & $25-45$ & $15-40$ & $25-45$ \\
\hline Optimum & 40 & 30 & 37 \\
\hline \multicolumn{4}{|l|}{$\mathrm{pH}$ for growth: } \\
\hline D-Mannose & - & + & + \\
\hline Maltose & - & + & ND \\
\hline Melibiose & - & + & ND \\
\hline D-Xylose & - & + & + \\
\hline Nitrate reduction & - & - & + \\
\hline Arginine dehydrolase & - & ND & + \\
\hline \multicolumn{4}{|l|}{ Hydrolysis of: } \\
\hline Casein & + & - & ND \\
\hline Aesculin & - & + & ND \\
\hline Urease activity & - & - & + \\
\hline DNA G + C content $(\mathrm{mol} \%)$ & 37.1 & 43 & 48 \\
\hline
\end{tabular}

$\beta$-galactosidase, lysine and ornithine decarboxylase, arginine dihydrolase and phenylalanine deaminase tests

Table 2. Cellular fatty acid compositions (\%) of strain $\mathrm{HS} 136^{\top}$ and closely related Bacillus species

Strains: 1, HS136 ${ }^{\mathrm{T}}$; 2, B. salarius $\mathrm{BH} 169^{\mathrm{T}}$ (Lim et al., 2006c); 3, B. qingdaonensis $\mathrm{CM}^{\mathrm{T}}$ (Wang et al., 2007).

\begin{tabular}{|lccc|}
\hline Fatty acid & $\mathbf{1}$ & $\mathbf{2}$ & $\mathbf{3}$ \\
\hline Iso-C $_{14: 0}$ & 0.5 & - & 1.6 \\
$\mathrm{C}_{14: 0}$ & 1.3 & - & 1.3 \\
$\mathrm{C}_{15: 0}$ & - & - & 1.2 \\
Iso-C $_{15: 0}$ & 41.6 & 8.9 & 5.9 \\
Anteiso-C & 35.8 & 53.1 & 34.8 \\
Iso-C $_{16: 0}$ & 1.3 & 6.6 & 14.0 \\
$\mathrm{C}_{16: 1} \omega 11 c$ & 1.5 & - & - \\
$\mathrm{C}_{16: 0}$ & 5.8 & - & 7.7 \\
Iso-C $_{17: 0}$ & 3.7 & - & 4.4 \\
Anteiso-C $_{17: 0}$ & 8.4 & 18.7 & 21.4 \\
$\mathrm{C}_{18: 0}$ & - & - & 2.1 \\
\hline
\end{tabular}

are negative. The following compounds are utilized as sole sources of carbon and energy: D-fructose, $m$-inositol, maltose, asparagine and cysteine. The following compounds are not utilized as sole sources of carbon and energy: D-glucose, galactose, lactose, D-mannose, melibiose, D-ribose, sucrose, glycerol, alanine, arginine, glycine, leucine, lysine, methionine, proline and valine. Sensitive to amoxicillin $(30 \mu \mathrm{g})$, carbenicillin $(100 \mu \mathrm{g})$, nitrofurantoin $(300 \mu \mathrm{g})$, tetracycline $(30 \mu \mathrm{g})$ and rifampicin $(5 \mu \mathrm{g})$. Resistant to gentamicin $(30 \mu \mathrm{g})$, tobramycin $(10 \mu \mathrm{g})$, kanamycin $(30 \mu \mathrm{g})$ and polymyxin $\mathrm{B}(100 \mathrm{U})$. Polar lipids are phosphatidylglycerol and diphosphatidylglycerol. The isoprenoid quinone is MK-7. The peptidoglycan type is A $1 \gamma$, with meso-diaminopimelic acid as the diagnostic diamino acid. Cellular fatty acids are iso- $\mathrm{C}_{15: 0}$, anteiso- $\mathrm{C}_{15: 0}$, anteiso- $\mathrm{C}_{17: 0}, \mathrm{C}_{16: 0}$, iso$\mathrm{C}_{17: 0}, \mathrm{C}_{16: 1} \omega 11 c$, iso- $\mathrm{C}_{16: 0}, \mathrm{C}_{14: 0}$ and iso- $\mathrm{C}_{14: 0}$. The DNA G $+\mathrm{C}$ content of the type strain is $37.1 \mathrm{~mol} \%\left(T_{\mathrm{m}}\right)$.

The type strain is $\mathrm{HS} 136^{\mathrm{T}} \quad\left(=\mathrm{CCM} \quad 7595^{\mathrm{T}}=\mathrm{DSM}\right.$ $\left.21632^{\mathrm{T}}=\mathrm{JCM} \quad 15720^{\mathrm{T}}=\mathrm{LMG} \quad 25222^{\mathrm{T}}\right)$, isolated from Howz-Soltan hypersaline lake in Iran. 


\section{Acknowledgements}

We thank J. Euzéby for his help with the etymology of the novel species' name. This study was supported by grants from the Iranian Environment Department (3/42274), the Spanish Ministerio de Educación y Ciencia (BIO2006-06927) and Junta de Andalucía (P06-CVI-01829).

\section{References}

Aino, K., Hirota, K., Matsuno, T., Morita, N., Nodasaka, Y., Fujiwara, T., Matsuyama, H., Yoshimune, K. \& Yumoto, I. (2008). Bacillus polygoni sp. nov., a moderately halophilic, non-motile obligate alkaliphile isolated from indigo balls. Int J Syst Evol Microbiol 58, 120-124.

Albuquerque, L., Tiago, I., Taborda, M., Nobre, M. F., Veríssimo, A. \& Da Costa, M. (2008). Bacillus isabeliae sp. nov., a halophilic bacterium isolated from a sea salt evaporation pond. Int J Syst Evol Microbiol 58, 226-230.

Amoozegar, M. A., Malekzadeh, F., Malik, K. A., Schumann, P. \& Spröer, C. (2003). Halobacillus karajensis sp. nov., a novel moderate halophile. Int J Syst Evol Microbiol 53, 1059-1063.

An, S. Y., Asahara, M., Goto, K., Kasai, H. \& Yokota, A. (2007a). Virgibacillus halophilus sp. nov., spore-forming bacteria isolated from soil in Japan. Int J Syst Evol Microbiol 57, 1607-1611.

An, S. Y., Kanoh, K., Kasai, H., Goto, K. \& Yokota, A. (2007b). Halobacillus faecis sp. nov., a spore-forming bacterium isolated from a mangrove area on Ishigaki Island, Japan. Int J Syst Evol Microbiol 57, 2476-2479.

Arahal, D. R. \& Ventosa, A. (2002). Moderately halophilic and halotolerant species of Bacillus and related genera. In Applications and Systematics of Bacillus and Relatives, pp. 83-99. Edited by R. Berkeley, M. Heyndrickx, N. Logan \& P. De Vos. Oxford: Blackwell.

Arahal, D. R., Márquez, M. C., Volcani, B. E., Schleifer, K. H. \& Ventosa, A. (1999). Bacillus marismortui sp. nov., a new moderately halophilic species from the Dead Sea. Int J Syst Bacteriol 49, 521-530.

Baron, E. J. \& Finegold, S. M. (1990). Bailey and Scott's Diagnostic Microbiology, 8th edn. St Louis, MO: Mosby.

Borsodi, A. K., Márialigeti, K., Szabó, G., Palatinszky, M., Pollák, B., Kéki, Z., Kovács, A. L., Schumann, P. \& Tóth, E. M. (2008). Bacillus aurantiacus sp. nov., an alkaliphilic and moderately halophilic bacterium isolated from Hungarian soda lakes. Int $J$ Syst Evol Microbiol 58, 845-851.

Cao, S. J., Qu, J. H., Yang, J. S., Sun, Q. \& Yuan, H. L. (2008). Halolactibacillus alkaliphilus sp. nov., a moderately alkaliphilic and halophilic bacterium isolated from a soda lake in Inner Mongolia, China, and emended description of the genus Halolactibacillus. Int $\mathrm{J}$ Syst Evol Microbiol 58, 2169-2173.

Carrasco, I. J., Márquez, M. C., Yanfen, X., Ma, Y., Cowan, D. A., Jones, B. E., Grant, W. D. \& Ventosa, A. (2006). Gracilibacillus orientalis sp. nov., a novel moderately halophilic bacterium isolated from a salt lake in Inner Mongolia, China. Int J Syst Evol Microbiol 56, 599-604.

Carrasco, I. J., Márquez, M. C., Xue, Y., Ma, Y., Cowan, D. A., Jones, B. E., Grant, W. D. \& Ventosa, A. (2007a). Bacillus chagannorensis sp. nov., a moderate halophile from a soda lake in Inner Mongolia, China. Int J Syst Evol Microbiol 57, 2084-2088.

Carrasco, I. J., Márquez, M. C., Xue, Y., Ma, Y., Cowan, D. A., Jones, B. E., Grant, W. D. \& Ventosa, A. (2007b). Salsuginibacillus kocurii gen. nov., sp. nov., a moderately halophilic bacterium from soda-lake sediment. Int J Syst Evol Microbiol 57, 2381-2386.

Carrasco, I. J., Márquez, M. C., Xue, Y., Ma, Y., Cowan, D. A., Jones, B. E., Grant, W. D. \& Ventosa, A. (2008). Sediminibacillus halophilus gen. nov., sp. nov., a moderately halophilic, Gram-positive bacterium from a hypersaline lake. Int J Syst Evol Microbiol 58, 1961-1967.

Cerritos, R., Vinuesa, P., Eguiarte, L. E., Herrera-Estrella, L., AlcarazPeraza, L. D., Arvizu-Gómez, J. L., Olmedo, G., Ramirez, E., Siefert, J. L. \& Souza, V. (2008). Bacillus coahuilensis sp. nov., a moderately halophilic species from a desiccation lagoon in the Cuatro Ciénegas Valley in Coahuila, Mexico. Int J Syst Evol Microbiol 58, 919-923.

Chen, Y. G., Cui, X. L., Fritze, D., Chai, L. H., Schumann, P., Wen, M. L., Wang, Y. X., Xu, L. H. \& Jiang, C. L. (2008). Virgibacillus kekensis sp. nov., a moderately halophilic bacterium isolated from a salt lake in China. Int J Syst Evol Microbiol 58, 647-653.

Chun, J., Lee, J.-H., Jung, Y., Kim, M., Kim, S., Kim, B. K. \& Lim, Y.-W. (2007). EzTaxon: a web-based tool for the identification of prokaryotes based on $16 \mathrm{~S}$ ribosomal RNA gene sequences. Int J Syst Evol Microbiol 57, 2259-2261.

Echigo, A., Fukushima, T., Mizuki, T., Kamekura, M. \& Usami, R. (2007). Halalkalibacillus halophilus gen. nov., sp. nov., a novel moderately halophilic and alkaliphilic bacterium isolated from a nonsaline soil sample in Japan. Int J Syst Evol Microbiol 57, 1081-1085.

Felsenstein, J. (1981). Evolutionary trees from DNA sequences: a maximum likelihood approach. J Mol Evol 17, 368-376.

Fitch, W. M. (1971). Toward defining the course of evolution: minimum change for a specific tree topology. Syst Zool 20, 406-416.

Garabito, M. J., Arahal, D. R., Mellado, E., Márquez, M. C. \& Ventosa, A. (1997). Bacillus salexigens sp. nov., a new moderately halophilic Bacillus species. Int J Syst Bacteriol 47, 735-741.

García, M. T., Gallego, V., Ventosa, A. \& Mellado, E. (2005). Thalassobacillus devorans gen. nov., sp. nov., a moderately halophilic, phenol-degrading, Gram-positive bacterium. Int J Syst Evol Microbiol 55, 1789-1795.

Harrigan, W. F. \& McCance, M. E. (1976). Laboratory Methods in Food and Dairy Microbiology. London: Academic Press.

Heyrman, J., Logan, N. A., Busse, H. J., Balcaen, A., Lebbe, L., Rodriguez-Diaz, M., Swings, J. \& De Vos, P. (2003). Virgibacillus carmonensis sp. nov., Virgibacillus necropolis sp. nov. and Virgibacillus picturae sp. nov., three novel species isolated from deteriorated mural paintings, transfer of the species of the genus Salibacillus to Virgibacillus, as Virgibacillus marismortui comb. nov. and Virgibacillus salexigens comb. nov., and emended description of the genus Virgibacillus. Int J Syst Evol Microbiol 53, 501-511.

Heyrman, J., Vanparys, B., Logan, N. A., Balcaen, A., Rodriguez-Diaz, M., Felske, A. \& De Vos, P. (2004). Bacillus novalis sp. nov., Bacillus vireti sp. nov., Bacillus soli sp. nov., Bacillus botaviensis sp. nov. and Bacillus drentensis sp. nov., from the Drentse A grasslands. Int J Syst Evol Microbiol 54, 47-57.

Heyrman, J., Rodriguez-Diaz, M., Devos, J., Felske, A., Logan, N. A. \& De Vos, P. (2005). Bacillus novalis sp. nov., Bacillus arvi sp. nov. and Bacillus humi sp. nov., isolated from soil. Int J Syst Evol Microbiol 55, 111-117.

Hua, N. P., Kanekiyo, A., Fujikura, K., Yasuda, H. \& Naganuma, T. (2007). Halobacillus profundi sp. nov. and Halobacillus kuroshimensis sp. nov., moderately halophilic bacteria isolated from a deep-sea methane cold seep. Int J Syst Evol Microbiol 57, 1243-1249.

Hua, N. P., Hamza-Chaffai, A., Vreeland, R. H., Isoda, H. \& Naganuma, T. (2008). Virgibacillus salarius sp. nov., a halophilic bacterium isolated from a Saharan salt lake. Int J Syst Evol Microbiol 58, 2409-2414.

Jeon, C. O., Lim, J. M., Lee, J. M., Xu, L. H., Jiang, C. L. \& Kim, C. J. (2005). Reclassification of Bacillus haloalkaliphilus Fritze 1996 as Alkalibacillus haloalkaliphilus gen. nov., comb. nov. and the description of Alkalibacillus salilacus sp. nov., a novel halophilic 
bacterium isolated from a salt lake in China. Int J Syst Evol Microbiol 55, 1891-1896.

Jeon, C. O., Lim, J. M., Jang, H. H., Park, D. J., Xu, L. H., Jiang, C. L. \& Kim, C. J. (2008). Gracilibacillus lacisalsi sp. nov., a halophilic Gram-positive bacterium from a salt lake in China. Int J Syst Evol Microbiol 58, 2282-2286.

Lee, J. S., Lim, J. M., Lee, K. C., Lee, J. C., Park, Y. H. \& Kim, C. J. (2006). Virgibacillus koreensis sp. nov., a novel bacterium from a salt field, and transfer of Virgibacillus picturae to the genus Oceanobacillus as Oceanobacillus picturae comb. nov. with emended descriptions. Int J Syst Evol Microbiol 56, 251-257.

Lee, J. C., Li, W. J., Xu, L. H., Jiang, C. L. \& Kim, C. J. (2008). Lentibacillus salis sp. nov., a moderately halophilic bacterium isolated from a salt lake. Int J Syst Evol Microbiol 58, 1838-1843.

Lim, J. M., Jeon, C. O., Song, S. M. \& Kim, C. J. (2005). Pontibacillus chungwhensis gen. nov., sp. nov., a moderately halophilic Grampositive bacterium from a solar saltern in Korea. Int J Syst Evol Microbiol 55, 165-170.

Lim, J.-M., Jeon, C. O. \& Kim, C.-J. (2006a). Bacillus taeanensis sp. nov., a halophilic Gram-positive bacterium from a solar saltern in Korea. Int J Syst Evol Microbiol 56, 2903-2908.

Lim, J.-M., Jeon, C. O., Lee, J. C., Ju, Y. J., Park, D. J. \& Kim, C.-J. (2006b). Bacillus koreensis sp. nov., a spore-forming bacterium, isolated from the rhizosphere of willow roots in Korea. Int J Syst Evol Microbiol 56, 59-63.

Lim, J.-M., Jeon, C. O., Lee, S.-M., Xu, L. H., Jiang, C.-L. \& Kim, C.-J. (2006c). Bacillus salarius sp. nov., a halophilic, spore-forming bacterium isolated from a salt lake in China. Int J Syst Evol Microbiol 56, 373-377.

Liu, W. Y., Zeng, J., Wang, L., Dou, Y. T. \& Yang, S. S. (2005). Halobacillus dabanensis sp. nov. and Halobacillus aidingensis sp. nov., isolated from salt lakes in Xinjiang, China. Int J Syst Evol Microbiol 55, 1991-1996.

Ludwig, W., Strunk, O., Westram, R., Richter, L., Meier, H., Yadhukumar, Buchner, A., Lai, T., Steppi, S. \& other authors (2004). ARB: a software environment for sequence data. Nucleic Acids Res 32, 1363-1371.

Marmur, J. (1961). A procedure for the isolation of deoxyribonucleic acid from microorganisms. J Mol Biol 3, 208-218.

Marmur, J. \& Doty, P. (1962). Determination of the base composition of deoxyribonucleic acid from its thermal denaturation temperature. J Mol Biol 5, 109-118.

Márquez, M. C., Carrasco, I. J., Xue, Y., Ma, Y., Cowan, D. A., Jones, B. E., Grant, W. D. \& Ventosa, A. (2008). Aquisalibacillus elongatus gen. nov., sp. nov., a moderately halophilic bacterium of the family Bacillaceae isolated from a saline lake. Int J Syst Evol Microbiol 58, 1922-1926.

Mata, J. A., Martinez-Canovas, J., Quesada, E. \& Bejar, V. (2002). A detailed phenotypic characterization of the type strains of Halomonas species. Syst Appl Microbiol 25, 360-375.

Murray, R. G. E., Doetsch, R. N. \& Robinow, F. (1994). Determinative and cytological light microscopy. In Methods for General and Molecular Bacteriology, pp. 21-41. Edited by P. Gerhardt, R. G. E. Murray, W. A. Wood \& N. R. Krieg. Washington, DC: American Society for Microbiology.

Namwong, S., Tanasupawat, S., Smitinont, T., Visessanguan, W., Kudo, T. \& Itoh, T. (2005). Isolation of Lentibacillus salicampi strains and Lentibacillus juripiscarius sp. nov. from fish sauce in Thailand. Int J Syst Evol Microbiol 55, 315-320.

Owen, R. J. \& Hill, L. R. (1979). The estimation of base compositions, base pairing and genome sizes of bacterial deoxyribonucleic acids. In Identification Methods for Microbiologists (Society for Applied
Bacteriology Technical Series no. 14), 2nd edn, pp. 277-296. Edited by F. A. Skinner \& D. W. Lovelock. London: Academic Press.

Pakdeeto, A., Tanasupawat, S., Thawai, C., Moonmangmee, S., Kudo, T. \& Itoh, T. (2007). Lentibacillus kapialis sp. nov., from fermented shrimp paste in Thailand. Int J Syst Evol Microbiol 57, 364-369.

Priest, F. G., Goodfellow, M. \& Todd, C. (1988). A numerical classification of the genus Bacillus. J Gen Microbiol 134, 1847-1882.

Quesada, E., Ventosa, A., Ruiz-Berraquero, F. \& RamosCormenzana, A. (1984). Deleya halophila, a new species of moderately halophilic bacteria. Int J Syst Bacteriol 34, 287-292.

Ren, P. G. \& Zhou, P. J. (2005a). Tenuibacillus multivorans gen. nov., sp. nov., a moderately halophilic bacterium isolated from saline soil in Xin-Jiang, China. Int J Syst Evol Microbiol 55, 95-99.

Ren, P. G. \& Zhou, P. J. (2005b). Salinibacillus aidingensis gen. nov., sp. nov. and Salinibacillus kushneri sp. nov., moderately halophilic bacteria isolated from a neutral saline lake in Xin-Jiang, China. Int J Syst Evol Microbiol 55, 949-953.

Romano, I., Finore, I., Nicolaus, G., Huertas, F. J., Lama, L., Nicolaus, B. \& Poli, A. (2008). Halobacillus alkaliphilus sp. nov., a halophilic bacterium isolated from a salt lake in Fuente de Piedra, southern Spain. Int J Syst Evol Microbiol 58, 886-890.

Saitou, N. \& Nei, M. (1987). The neighbor-joining method: a new method for reconstructing phylogenetic trees. Mol Biol Evol 4, 406-425.

Schlesner, H., Lawson, P. A., Collins, M. D., Weiss, N., Wehmeyer, U., Völker, H. \& Thomm, M. (2001). Filobacillus milensis gen. nov., sp. nov., a new halophilic spore-forming bacterium with Orn-D-Glu-type peptidoglycan. Int J Syst Evol Microbiol 51, 425-431.

Smibert, R. M. \& Krieg, N. R. (1994). Phenotypic characterization. In Methods for General and Molecular Bacteriology, pp. 607-654. Edited by P. Gerhardt, R. G. E. Murray, W. A. Wood \& N. R. Krieg. Washington, DC: American Society for Microbiology.

Soto-Ramírez, N., Sánchez-Porro, C., Rosas-Padilla, S., Almodóvar, K., Jiménez, G., Machado-Rodríguez, M., Zapata, M., Ventosa, A. \& Montalvo-Rodríguez, R. (2008). Halobacillus mangrovi sp. nov., a moderately halophilic bacterium isolated from the black mangrove Avicennia germinans. Int J Syst Evol Microbiol 58, 125-130.

Spring, S., Ludwig, W., Marquez, M. C., Ventosa, A. \& Schleifer, K.-H. (1996). Halobacillus gen. nov., with descriptions of Halobacillus litoralis sp. nov. and Halobacillus trueperi sp. nov., and transfer of Sporosarcina halophila to Halobacillus halophilus comb. nov. Int J Syst Bacteriol 46, 492-496.

Stackebrandt, E. \& Ebers, J. (2006). Taxonomic parameters revisited: tarnished gold standards. Microbiol Today 33, 152-155.

Stackebrandt, E. \& Goebel, B. M. (1994). Taxonomic note: a place for DNA-DNA reassociation and $16 \mathrm{~S}$ rRNA sequence analysis in the present species definition in bacteriology. Int J Syst Bacteriol 44, 846-849.

Stackebrandt, E., Fredericksen, W., Garrity, G. M., Grimont, P. A. D., Kampfer, P., Maiden, M. C. J., Nesme, X., Rossello-Mora, R., Swings, J. \& other authors (2002). Report of the ad hoc committee for the re-evaluation of the species definition in bacteriology. Int $J$ Syst Evol Microbiol 52, 1043-1047.

Tanasupawat, S., Namwong, S., Kudo, T. \& Itoh, T. (2007). Piscibacillus salipiscarius gen. nov., sp. nov., a moderately halophilic bacterium from fermented fish (pla-ra) in Thailand. Int J Syst Evol Microbiol 57, 1413-1417.

Usami, R., Echigo, A., Fukushima, T., Mizuki, T., Yoshida, Y. \& Kamekura, M. (2007). Alkalibacillus silvisoli sp. nov., an alkaliphilic moderate halophile isolated from non-saline forest soil in Japan. Int J Syst Evol Microbiol 57, 770-774.

Ventosa, A. (2006). Unusual micro-organisms from unusual habitats: hypersaline environments. In Prokaryotic Diversity - Mechanisms and 
Significance (Society for General Microbiology Symposium no. 66), pp. 223-253. Edited by N. A. Logan, H. M. Lappin-Scott \& P. C. F. Oyston. Cambridge: Cambridge University Press.

Ventosa, A., Quesada, E., Rodriguez-Valera, F., Ruiz-Berraquero, F. \& Ramos-Cormenzana, A. (1982). Numerical taxonomy of moderately halophilic Gram-negative rods. J Gen Microbiol 128, 1959-1968.

Ventosa, A., García, M. T., Kamekura, M., Onishi, H. \& RuizBerraquero, F. (1989). Bacillus halophilus sp. nov., a moderately halophilic Bacillus species. Syst Appl Microbiol 12, 162-166.

Ventosa, A., Nieto, J. J. \& Oren, A. (1998). Biology of moderately halophilic aerobic bacteria. Microbiol Mol Biol Rev 62, 504-544.

Wainø, M., Tindall, B. J., Schumann, P. \& Ingvorsen, K. (1999). Gracilibacillus gen. nov., with description of Gracilibacillus halotolerans gen. nov., sp. nov.; transfer of Bacillus dipsosauri to Gracilibacillus dipsosauri comb. nov., and Bacillus salexigens to the genus Salibacillus gen. nov., as Salibacillus salexigens comb. nov. Int J Syst Bacteriol 49, 821-831.

Wang, Q. F., Li, W., Liu, Y. L., Cao, H. H., Li, Z. \& Guo, G. Q. (2007). Bacillus qingdaonensis sp. nov., a moderately haloalkaliphilic bacterium isolated from a crude sea-salt sample collected near Qingdao in eastern China. Int J Syst Evol Microbiol 57, 1143-1147.

Wang, C. Y., Chang, C. C., Ng, C. C., Chen, T. W. \& Shyu, Y. T. (2008). Virgibacillus chiguensis sp. nov., a novel halophilic bacterium isolated from Chigu, a previously commercial saltern located in southern Taiwan. Int J Syst Evol Microbiol 58, 341-345.

Wieser, M., Worliczek, H., Kämpfer, P. \& Busse, H.-J. (2005). Bacillus herbersteinensis sp. nov. Int J Syst Evol Microbiol 55, 2119-2123.

Yoon, J. H., Kang, K. H. \& Park, Y. H. (2002). Lentibacillus salicampi gen. nov., sp. nov., a moderately halophilic bacterium isolated from a salt field in Korea. Int J Syst Evol Microbiol 52, 2043-2048.
Yoon, J. H., Kang, K. H. \& Park, Y. H. (2003). Halobacillus salinus sp. nov., isolated from a salt lake on the coast of the East Sea in Korea. Int J Syst Evol Microbiol 53, 687-693.

Yoon, J. H., Kim, I. G., Schumann, P., Oh, T. K. \& Park, Y. H. (2004a). Marinibacillus campisalis sp. nov., a moderate halophile isolated from a marine solar saltern in Korea, with emended description of the genus Marinibacillus. Int J Syst Evol Microbiol 54, 1317-1321.

Yoon, J.H., Oh, T.K. \& Park, Y.H. (2004b). Transfer of Bacillus halodenitrificans Denariaz et al. 1989 to the genus Virgibacillus as Virgibacillus halodenitrificans comb. nov. Int J Syst Evol Microbiol 54, 2163-2167.

Yoon, J. H., Kang, S. J., Lee, C. H., Oh, H. W. \& Oh, T. K. (2005). Halobacillus yeomjeoni sp. nov., isolated from a marine solar saltern in Korea. Int J Syst Evol Microbiol 55, 2413-2417.

Yoon, J. H., Kang, S. J., Jung, Y. T. \& Oh, T. K. (2007a). Halobacillus campisalis sp. nov., containing meso-diaminopimelic acid in the cellwall peptidoglycan, and emended description of the genus Halobacillus. Int J Syst Evol Microbiol 57, 2021-2025.

Yoon, J.H., Kang, S.J. \& Oh, T.K. (2007b). Reclassification of Marinococcus albus Hao et al. 1985 as Salimicrobium album gen. nov., comb. nov. and Bacillus halophilus Ventosa et al. 1990 as Salimicrobium halophilum comb. nov., and description of Salimicrobium luteum sp. nov. Int J Syst Evol Microbiol 57, 2406-2411.

Yoon, J. H., Kang, S. J. \& Oh, T. K. (2008). Halobacillus seohaensis sp. nov., isolated from a marine solar saltern in Korea. Int J Syst Evol Microbiol 58, 622-627.

Yumoto, I., Hirota, K., Goto, T., Nodasaka, Y. \& Nakajima, K. (2005). Bacillus oshimensis sp. nov., a moderately halophilic, non-motile alkaliphile. Int J Syst Evol Microbiol 55, 907-911. 